\title{
Badania podatności skały złożowej typu tight gas na zjawisko embedment ograniczające efektywność zabiegu hydraulicznego szczelinowania
}

\begin{abstract}
W artykule przedstawiono zagadnienia związane z technologią hydraulicznego szczelinowania skał piaskowcowych typu zamkniętego (ang. tight gas). Zaprezentowano, jaki wpływ na efektywność zabiegu hydraulicznego szczelinowania skały złożowej ma zjawisko wgniatania ziaren podsadzki w ściany szczeliny (ang. embedment). Związane jest ono z tworzeniem się wgnieceń na powierzchni ściany szczeliny, a tym samym spadkiem rozwartości szczeliny po zabiegu szczelinowania. Opracowano metodykę badania podatności skały złożowej na zjawisko embedment ograniczające efektywne podsadzenie szczeliny oraz zweryfikowano ją badaniami laboratoryjnymi. Testy wykonano dla skały piaskowcowej typu zamkniętego tight gas, pochodzącej z polskiego złoża niekonwencjonalnego, dla suchych i nasyconych płynem szczelinującym cylindrycznych rdzeni, przy jednej wartości naprężenia ściskającego $82,7 \mathrm{MPa}\left(\mathrm{tj} .12000 \mathrm{psi}\right.$ ), temperatury pokojowej oraz koncentracji powierzchniowej podsadzki 4,88 kg/m² (tj. $\left.1 \mathrm{lb} / \mathrm{ft}^{2}\right)$. Do podsadzenia szczeliny użyto podsadzki ceramicznej o rozmiarze ziaren $0,850 \div 0,425 \mathrm{~mm}$. W pierwszej kolejności wyznaczono rozwartość szczeliny wypełnionej podsadzką pomiędzy dwiema cylindrycznymi kształtkami stalowymi (dla wykluczenia zjawiska embedment). Po 6 godzinach oddziaływania zadanego naprężenia ściskającego maksymalna (pierwotna) rozwartość szczeliny wyniosła $2,286 \mathrm{~mm}$. Dla suchych cylindrycznych rdzeni skalnych z piaskowca tight gas uzyskano szczelinę o rozwartości 1,893 $\mathrm{mm}$. Efektywne podsadzenie szczeliny proppantem wyniosło $82,8 \%$. Natomiast dla rdzeni skalnych dodatkowo nasyconych płynem szczelinującym otrzymano rozwartość szczeliny $1,889 \mathrm{~mm}$, a więc efektywność podsadzenia szczeliny osiągnęła wartość $82,6 \%$. Zastosowana procedura badawcza może stanowić jedną z metod oceny podatności skały złożowej na zjawisko embedment ograniczające efektywne podsadzenie szczeliny materiałem podsadzkowym. Może być też przydatna do prawidłowego doboru technologii szczelinowania, płynu szczelinującego i podsadzki w zabiegach szczelinowania złóż węglowodorów.
\end{abstract}

Słowa kluczowe: niekonwencjonalne złoża węglowodorów, hydrauliczne szczelinowanie, proppant, embedment, rozwartość szczeliny, materiał podsadzkowy, efektywne podsadzenie szczeliny.

\section{Studies of the susceptibility of the tight gas rock to the phenomenon of embedment, limiting the effectiveness of hydraulic fracturing}

This paper presents, a study on the impact of proppant embedment into the fracture walls, on the effectiveness of hydraulic fracturing in tight formations. The methodology for the evaluation of the susceptibility of reservoir rock to the embedment phenomenon (limiting the effective propping of fractures) was developed and verified in laboratory tests. The studies were performed for tight gas sandstone representing unconventional Polish deposits, for dry and fracfluid-wet cores, at 12000 psi compressive stress, at room temperature and $1 \mathrm{lb} / \mathrm{ft}^{2}$ surface concentration of proppant. Ceramic proppant of grain size between $0.850 \div 0.425 \mathrm{~mm}$ was used. First, the fracture between cylindrical steel plates (no embedment assumed) was propped. After 6 hours under constant compressive stress, the maximum (original) fracture width was $2.286 \mathrm{~mm}$. The fracture between dry cylindrical sandstone tight gas cores, in the same conditions was $1.893 \mathrm{~mm}$ wide. The effective value of propped fracture width was $82.8 \%$. The width of the fracture in fracfluid-wet core was $1.889 \mathrm{~mm}$. In this case the effective value of the propped fracture width was $82.6 \%$. The test procedure we applied, might be used in the evaluation of the susceptibility of reservoir rock to the embedment phenomenon, as well as for the selection of fracfluid and proppant for hydrocarbon reservoirs fracturing.

Key words: unconventional reservoirs, tight gas, hydraulic fracturing, proppant, embedment, width fracture, effective propped fracture. 


\section{Wstęp}

Wydobycie węglowodorów ze złóż niekonwencjonalnych jest stosunkowo nową gałęzią przemysłu naftowego. Złoża niekonwencjonalne to między innymi: formacje łupkowe (ang. shale gas) oraz piaskowce typu zamkniętego (ang. $t i-$ ght gas) $[3,4,11-13,15,20]$. Te ostatnie charakteryzują się małą przepuszczalnością i porowatością. Ich przepuszczalność dla gazu mieści się w zakresie $0,1 \div 0,01 \mathrm{mD}[7,11-13$, 15]. W skale tej podstawowym składnikiem budującym matrycę skalną jest kwarc. Charakteryzuje się ona niskim stopniem plastyczności oraz wysokim modułem Younga i niskim współczynnikiem Poisson'a, a tym samym łatwiej tworzą się w niej szczeliny oraz spękania charakterystyczne dla skał „kruchych” [8, 9, 12]. Eksploatacja takich złóż odbywa się poprzez odwierty pionowe, horyzontalne (poziome) oraz wielodenne. Do prowadzenia efektywnej eksploatacji węglowodorów z tego typu złóż niezbędne jest wykonanie w nich zabiegów hydraulicznego szczelinowania, podczas których wytworzone szczeliny wypełnia się materiałem podsadzkowym zapewniającym pozostanie ich w stanie rozwarcia po zakończonym zabiegu. Do szczelinowania złóż niekonwencjonalnych typu zamkniętego tight gas stosuje się najczęściej technologie sieciowanych polimerów liniowych [12]. Płyny szczelinujące charakteryzują się właściwościami reologicznymi zbliżonymi do parametrów płynów stosowanych do zabiegów hydraulicznego szczelinowania złóż konwencjonalnych. W przypadku złóż o niskiej temperaturze, gdzie nie jest zapewniona sprawna degradacja polimeru, zaleca się wykonywać tzw. zabiegi hybrydowe $[11,12,15]$. Przeprowadza się je z wykorzystaniem dwóch różnych płynów szczelinujących. Płyn o niewielkiej lepkości (technologia polimerów liniowych lub technologia slickwater) jest wykorzystywany do inicjacji i propagacji szczeliny. Po nim wtłacza się płyn na bazie sieciowanego polimeru o niskiej koncentracji polimeru, który służy do zwiększania rozwartości szczeliny i transportu materiału podsadzkowego. Te dwa płyny wtłacza się naprzemiennie w wieloetapowym procesie szczelinowania. Główny płyn szczelinujący jest zatłaczany ze zwiększoną wydajnością. Do szczelinowania złóż niekonwencjonalnych typu tight gas stosuje się również płyny na bazie żeli oraz piany.

\section{System tworzenia się szczelin oraz pęknięć podczas zabiegu hydraulicznego szczelinowania złóż niekonwencjonalnych typu zamkniętego tight gas}

Aby zabiegi stymulacyjne w piaskowcach typu zamkniętego tight gas były skuteczne, należy wytworzyć w nich szczeliny, pęknięcia umożliwiające uwolnienie się z nich gazu oraz przepływ płynów złożowych z sieci porów do odwiertu [7, 12, 13, 15-18]. Wytworzone szczeliny i spękania w takich piaskowcach charakteryzują się małą rozwartością oraz dużymi wartościami współczynnika SRV (Sti- mulated Reservoir Volume), zwiększonym zasięgiem objętościowym w złoże, umożliwiającym ich kontakt z naturalnymi szczelinami. Geometria wytworzonych szczelin jest złożona i zależna od obszarów zdolnych do pękania. System wytworzonych szczelin przedstawionych na rysunku 1 pozwala na uzyskanie dużej powierzchni kontaktu złoża z odwiertem.

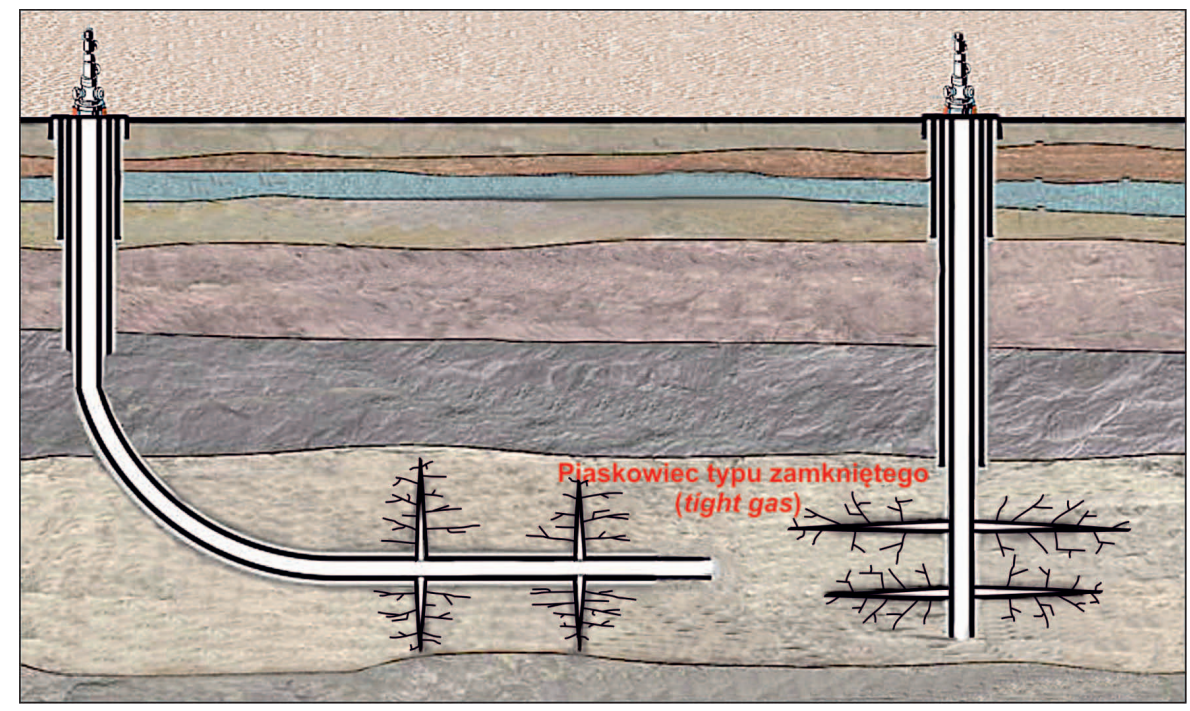

Rys. 1. Schemat tworzenia szczelin podczas zabiegu hydraulicznego szczelinowania z podsadzką dla piaskowca typu zamkniętego tight gas [14, 16, 17, 22] 


\section{Podatność skały złożowej na zjawisko embedment ograniczające efektywne podsadzenie szczeliny materiałem podsadzkowym}

Oprócz sposobu transportu i umieszczania materiału podsadzkowego w wytworzonej szczelinie, na efektywne jej podsadzenie oraz uzyskanie odpowiedniej przepuszczalności i przewodności wpływa również podatność skały złożowej na zjawisko embedment $[12,13,15,19,20,22]$. Związane jest ono z podatnością skały na wgniatanie ziaren materiału podsadzkowego w ściany szczeliny, występującą po zabiegu hydraulicznego szczelinowania. To niekorzystne zjawisko wpływa na uszkodzenie strefy w otoczeniu ściany szczeliny i zmniejszenie się rozwartości $W_{f}$ wytworzonej szczeliny (rysunek 2), a tym samym - zmniejszenie przepuszczalności i przewodności szczeliny wypełnionej podsadzką $[10,12,19,20,21,23]$.

Wielkość efektu wgniatania ziaren podsadzki w ścianę szczeliny zależy między innymi od: rodzaju skały złożowej (tj. składu mineralogicznego), właściwości mechanicznych skały złożowej (tj. modułu Younga, współczynnika Poisson’a), rodzaju materiału podsadzkowego, wielkości naprężeń ściskających w złożu, czasu oddziaływania naprężeń ściskających, rodzaju płynów szczelinujących i złożowych, temperatury oraz technologii eksploatacji złoża. Może tutaj również dochodzić do kruszenia się ziaren skały złożowej w okolicach ściany szczeliny, powodującego wzrost zagęszczania się ich okruchów w tej strefie. Wpływa to na ograniczenie przepływu węglowodorów ze skały złożowej do podsadzonej proppantem szczeliny [12, 15, 19, 20].

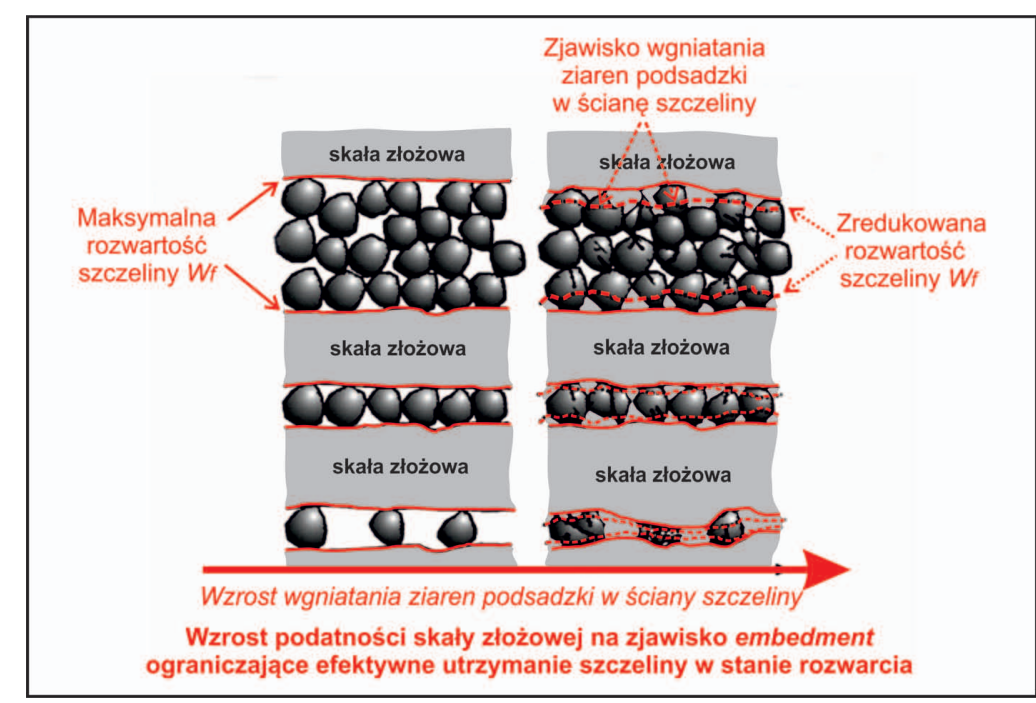

Rys. 2. Wpływ podatności skały złożowej na zjawisko embedment ograniczające efektywne utrzymanie rozwartości szczeliny wypełnionej podsadzką po zabiegu hydraulicznego szczelinowania $[10,12,21]$

\section{Metodyka badania podatności skały złożowej na zjawisko embedment ograniczające efektywność zabiegu hydraulicznego szczelinowania}

Prawidłowe wykonanie laboratoryjnej symulacji podatności skały złożowej na zjawisko wgniatania ziaren podsadzki w ściany szczeliny, ograniczające efektywne podsadzenie szczeliny materiałem podsadzkowym, oraz analiza uzyskanych wyników wymagają wykonania poniżej przedstawionych działań

- Scharakteryzowanie parametrów złożowych oraz technologii wykonania zabiegu hydraulicznego szczelinowania złoża $[5,12,15]$.

W tym celu należy zebrać informacje dotyczące: głębokości odwiertu dla wykonania zabiegu szczelinowania, temperatury złożowej, wartości ciśnień i naprężeń panujących w złożu (ciśnienie zamknięcia szczeliny), czasu zamykania się szczeliny w warunkach złożowych, rodzaju płynów złożowych, typu i koncentracji materiału podsadzkowego, rodzaju płynów użytych do zabiegu szczelinowania oraz przewidywanego zasięgu szczelin wytworzonych w wyniku wykonania zabiegu.

- Określenie właściwości skały użytej do badań $[1,2,6$, $12,15,20]$.
Do właściwości skały złożowej zaliczamy między innymi: skład mineralogiczny oraz jej właściwości mechaniczne (statyczny i dynamiczny moduł Younga oraz współczynnik Poisson'a).

- Wyznaczenie podstawowych właściwości materiału podsadzkowego [12, 15, 22, 24-26].

Podstawowe badania mają na celu stwierdzenie, czy poddany analizie materiał podsadzkowy może być stosowany jako proppant do zabiegów hydraulicznego szczelinowania złóż. Wykonuje się je w oparciu o szczegółowo opisane procedury pomiarowe zawarte w normach [12, 15, 24-26].

- Przygotowanie próbek skały do badań $[12,15]$. Próbki użyte do badań powinny pochodzić ze skały złożowej odpowiadającej głębokości wykonania zabiegu hydraulicznego szczelinowania. $Z$ pobranych rdzeni wiertniczych wycina się cylindryczne rdzenie o średnicy $3,81 \mathrm{~cm}$ (1,5 cala) lub $2,54 \mathrm{~cm}$ (1 cala). Ważne jest, aby wszystkie cylindryczne rdzenie umożliwily uzyskanie w badaniach porównywalnej wielkości powierzchni ściany szczeliny dostępnej 
dla kontaktu jej z materiałem podsadzkowym. Dodatkowo czoła wyciętych cylindrycznych rdzeni wyrównuje się oraz wygładza tak, aby z powierzchnią boczną tworzyły kąt prosty. Kolejno określa się dla nich średnicę, długość oraz współczynnik przepuszczalności i porowatości.

- Wyznaczenie chropowatości powierzchni ściany szczeliny $[12,15,18]$.

Przed wciskaniem ziaren podsadzki w ścianę szczeliny należy wykonać zdjęcie pierwotnej powierzchni ściany szczeliny oraz określić jej chropowatość. Chropowatość wyznacza się pod mikroskopem stereoskopowym umożliwiającym cyfrowe obrazowanie oraz analizę chropowatości powierzchni szczeliny. Dla kilku wytypowanych obszarów na powierzchni ściany szczeliny wykonuje się ich cyfrowy obraz, a następnie dla każdego z nich wyznacza się średnią chropowatość z kilku profili chropowatości wzdłuż wytypowanych odcinków pomiarowych. Metodę wyznaczenia chropowatości powierzchni wzdłuż danego odcinka pomiarowego przedstawiono na rysunku 3 oraz przy użyciu równań (1 i 2) [12, 15, 18].

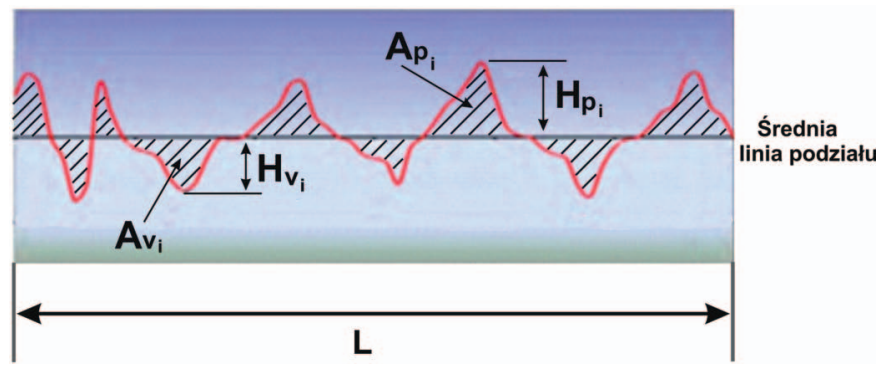

Rys. 3. Przykładowy profil chropowatości powierzchni wzdłuż odcinka pomiarowego dla wytypowanego obszaru na powierzchni czołowej ściany szczeliny $[12,15,18]$

Położenie średniej linii podziału profilu chropowatości musi spełniać warunek przedstawiony równaniem $[12,15]$ :

$$
\sum_{i=0}^{n} A_{p_{i}}=\sum_{i=0}^{n} A_{v_{i}}
$$

gdzie:

$A_{p}$ - pole powierzchni pomiędzy krzywą szczytu a średnią linią podziału $\left[\mathrm{mm}^{2}\right]$,

$A_{v}$ - pole powierzchni pomiędzy krzywą doliny a średnią linią podziału $\left[\mathrm{mm}^{2}\right]$.

Chropowatość profilu wyznacza równanie (2):

$$
R=\frac{\sum_{i=0}^{n} H_{p_{i}}+\sum_{i=0}^{n} H_{v_{i}}}{n_{p}+n_{v}}
$$

gdzie:

$R$ - chropowatość profilu powierzchni wzdłuż odcinka pomiarowego $[\mu \mathrm{m}]$,
$H_{p}$ - wysokość szczytu [mm],

$H_{v}$ - głębokość doliny [mm],

$n_{p}$ - liczba wszystkich szczytów [-],

$n_{v}-$ liczba wszystkich dolin [-].

Średnią chropowatość $R_{s r}$ dla całej powierzchni ściany szczeliny określa się jako średnią arytmetyczną z chropowatości profili wyznaczonych dla poszczególnych wytypowanych obszarów.

\section{Laboratoryjna symulacja podatności skały złożowej na zjawisko embedment ograniczające efektywne podsadzenie wytworzonej szczeliny}

W celu laboratoryjnego badania podatności skały złożowej na zjawisko wgniatania ziaren podsadzki w ściany szczeliny, ograniczające efektywne utrzymanie szczeliny w stanie rozwarcia po zabiegu hydraulicznego szczelinowania, należy wytworzyć szczelinę wypełnioną podsadzką, a następnie poddać ją działaniu zadanego naprężenia ściskającego (rysunek 4) [12, 15].

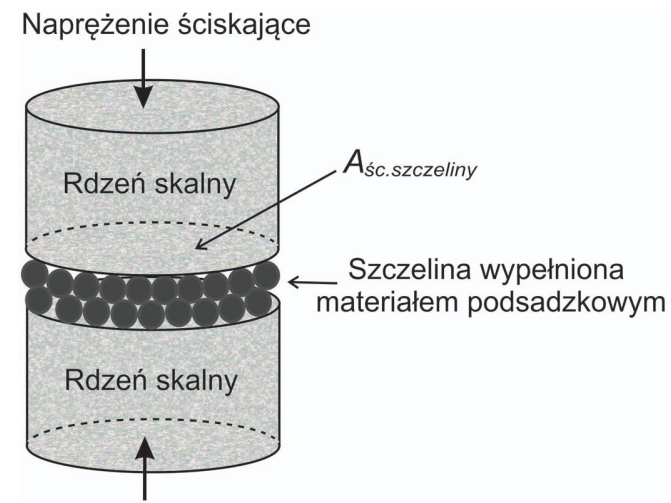

Rys. 4. Schemat umieszczenia materiału podsadzkowego w wytworzonej szczelinie podczas badania podatności skały złożowej na zjawisko embedment $[12,15]$

Ilość materiału podsadzkowego potrzebną do wypełnienia szczeliny dla uzyskania zadanej koncentracji powierzchniowej określa się według równania $[12,15,27]$ :

$$
m_{p}=0,1 \cdot A_{s c . s z c z e l i n y} \cdot C
$$

gdzie:

$m_{p}$ - masa podsadzki [g],

$C$ - koncentracja powierzchniowa podsadzki $\left[\mathrm{kg} / \mathrm{m}^{2}\right]$,

$A_{\text {śc.szczeliny }}$ - pole powierzchni ściany szczeliny poddawanej naprężeniu ściskającemu $\left[\mathrm{cm}^{2}\right]$.

W przypadku zastosowania cylindrycznej komory do badania podatności skały złożowej na zjawisko embedment, przedstawionej na rysunku 8 a, pole powierzchni ściany szczeliny $A_{\text {śc.szczeliny }}$ określa się według równania $[12,15]$ : 


$$
A_{\text {śc.szczeliny }}=\frac{\pi \cdot d_{w}^{2}}{4}
$$

gdzie:

$d_{w}$ - wewnętrzna średnica cylindrycznej komory użytej do badań zjawiska wciskania ziaren podsadzki w ściany szczeliny [cm].

Następnie odważony materiał podsadzkowy $m_{p}$ umieszcza się równolegle i równomiernie wewnątrz komory cylindrycznej (rysunek 8a) pomiędzy dwiema powierzchniami czołowymi cylindrycznych rdzeni (rysunki 4 i 8b) o średnicy odpowiadającej wewnętrznej średnicy $d_{w}$ komory cylindrycznej $[12,15]$. Tak przygotowaną komorę zamyka się powoli tłokiem, a następnie umieszcza się na prasie hydraulicznej. Po uzyskaniu stałej temperatury w komorze, rdzenie i podsadzkę poddaje się działaniu zadanego naprężenia ściskającego. Siłę $F_{t c}$, potrzebną do wytworzenia zadanego naprężenia ściskającego, określa się według równania $[12,15,24,25]$ :

$$
F_{t c}=\frac{\pi \cdot \sigma \cdot d_{w}^{2}}{4}
$$

gdzie:

$F_{t c}-$ siła potrzebna do uzyskania zadanego nacisku [N], $\sigma$ - naprężenie działające na skałę i podsadzkę [MPa], $d_{w}$ - wewnętrzna średnica cylindrycznej komory [mm]

Do zadanej wartości naprężenia ściskającego dochodzi się ze stałą prędkością, a po jego osiągnięciu kontynuowany jest nacisk na podsadzkę przez zadany czas, a następnie powoli zdejmuje się naprężenie i tłok z komory.

\section{Określenie całkowitej średniej głębokości wgnieceń ziaren podsadzki w ściany szczeliny oraz całkowitego średniego procentowego uszkodzenia powierzchni ścian szczeliny, po upływie czasu oddziaływania zadanego naprężenia ściskającego [12, 15]}

Głębokość wgnieceń ziaren podsadzki w ścianę szczeliny wyznacza się pod mikroskopem stereoskopowym umożliwiającym cyfrowe obrazowanie powierzchni oraz głębokości wgnieceń. Polega to na wykonaniu cyfrowego obrazu powierzchni ściany szczeliny w 3D, dla kilku wytypowanych na niej obszarów. Następnie dla każdego z nich określa się średnią głębokość oraz średni procentowy rozmiar uszkodzenia z profili głębokości wzdłuż kilku odcinków pomiarowych (profili głębokości). Metodę wyznaczenia głębokości wgnieceń oraz procentowe uszkodzenie powierzchni szczeliny wzdłuż odcinka pomiarowego przedstawiono na rysunku 5 oraz przy pomocy równań $(1,6-9)$ [12, 15].

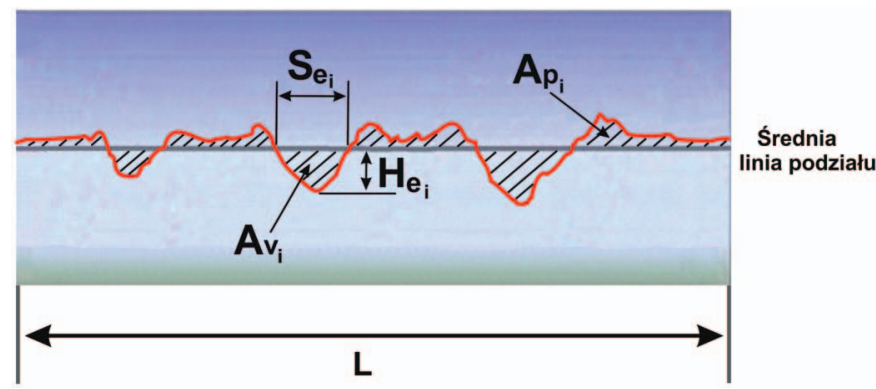

Rys. 5. Przykładowy profil głębokości wgnieceń ziaren podsadzki wzdłuż odcinka pomiarowego dla wytypowanego obszaru na powierzchni ściany szczeliny $[12,15]$

$$
H_{e}=\frac{\sum_{i=0}^{n} H_{e_{i}}}{n_{e}}
$$

gdzie:

$H_{e}$ - średnia głębokość wgnieceń ziaren podsadzki w ścianę szczeliny dla profilu, wzdłuż odcinka pomiarowego [mm],

$H_{e_{i}}$ - głębokość doliny (wgniecenie ziarna podsadzki w ścianę szczeliny) [mm],

$n_{e}-$ liczba wszystkich dolin (wgnieceń ziaren podsadzki w ścianę szczeliny) [-].

Całkowitą średnią głębokość $H_{e_{c}}$ wgnieceń ziaren podsadzki w ściany szczeliny [mm] określa się według równania $[12,15]$ :

$$
H_{e_{c}}=H_{e_{s} r . g}+H_{e_{s} r . d}
$$

gdzie:

$H_{e_{s} r g}$ - średnia głębokość wgnieceń ziaren podsadzki w górną ścianę szczeliny, będąca średnią arytmetyczną ich wartości dla poszczególnych wytypowanych obszarów [mm],

$H_{e^{s} r . d}$ - średnia głębokość wgnieceń ziaren podsadzki w dolną ścianę szczeliny, będąca średnią arytmetyczną ich wartości dla poszczególnych wytypowanych obszarów [mm].

$$
P_{P}=\frac{\sum_{i=0}^{n} S_{e_{i}}}{L} \cdot 100
$$

gdzie:

$P U S_{e}$ - procentowe uszkodzenie powierzchni ściany szczeliny (wgniecenia ziaren podsadzki na powierzchni ściany szczeliny) dla profilu, tj. wzdłuż odcinka pomiarowego [\%],

$S_{e_{i}}$ - szerokość doliny (wgniecenie ziarna podsadzki na powierzchni ściany szczeliny) [mm],

$L$-długość odcinka pomiarowego [mm]. 
Całkowite średnie procentowe uszkodzenie $P U S_{e c}$ powierzchni ścian szczeliny (wgniecenia ziaren podsadzki w ścianę szczeliny) określa się według równania $[12,15]$ :

$$
P U S_{e_{c}}=\frac{P U S_{e_{s r . g}}+P U S_{e_{s r . d}}}{2}
$$

gdzie:

$P U S_{e_{s s r g}}$ - średnie procentowe uszkodzenie powierzchni górnej ściany szczeliny, czyli wgniecenia ziaren podsadzki na powierzchni ściany szczeliny, będące średnią arytmetyczną ich wartości dla poszczególnych wytypowanych obszarów [\%],

$P U S_{e_{s}^{s} \cdot d}$ - średnie procentowe uszkodzenie powierzchni dolnej ściany szczeliny, czyli wgniecenia ziaren podsadzki na powierzchni ściany szczeliny, będące średnią arytmetyczną ich wartości dla poszczególnych wytypowanych obszarów [\%].

$$
P S W_{f}=\frac{H_{e_{c}}}{W_{f_{m}}} \cdot 100
$$

gdzie:

$P S W_{f}$ - procentowy spadek rozwartości szczeliny wypełnionej materiałem podsadzkowym, związany ze zjawiskiem embedment [\%],

$W_{f_{m}}$ - rozwartość szczeliny wypełnionej materiałem podsadzkowym bez występowania zjawiska embedment $[\mathrm{mm}]$.

Rozwartość szczeliny wypełnionej materiałem podsadzkowym $W_{f_{m}}$ bez występowania zjawiska embedment określa się według wcześniej przedstawionej procedury badawczej.
W badaniu tym zamiast cylindrycznych rdzeni skalnych stosuje się stalowe kształtki cylindryczne, charakteryzujące się twardością stali większą od 43 w skali C Rockwella (HRC) [24, 26]. Prasę hydrauliczną należy dodatkowo wyposażyć w szczelinościomierz LVDT. Przez cały czas badania mierzy się rozwartość $W_{f_{m}}$ szczeliny wypełnionej materiałem podsadzkowym pomiędzy dwiema kształtkami stalowymi za pomocą szczelinościomierza LVDT. Wskazania LVDT wysokości szczeliny należy skorygować o wielkość odkształcenia stanowiska badawczego (tj. prasy hydraulicznej, komory pomiarowej oraz cylindrycznych kształtek stalowych) $[12,15]$.

\section{Określenie parametru efektywnego podsadzenia szczeliny proppantem}

Efektywne podsadzenie szczeliny EPS materiałem podsadzkowym po zabiegu hydraulicznego szczelinowania określa się według równania (11):

$$
E P S=\frac{W_{f}}{W_{f_{m}}} \cdot 100
$$

gdzie:

$W_{f}$ - rozwartość szczeliny wypełnionej materiałem podsadzkowym z uwzględnieniem zjawiska embedment $[\mathrm{mm}]$, którą określa się według równania (12),

$W_{f_{m}}$ - rozwartość szczeliny wypełnionej materiałem podsadzkowym bez występowania zjawiska embedment $[\mathrm{mm}]$.

$$
W_{f}=W_{f_{m}}-H_{e_{c}}
$$

\section{Charakterystyka skały złożowej, płynu szczelinującego oraz materiału podsadzkowego, które zostały użyte do badań}

Złoża niekonwencjonalne typu zamkniętego tight gas występują w Polsce najczęściej na średnich i dużych głębokościach, rzędu $3000 \div 4500 \mathrm{~m}$. Charakteryzują się one wysokimi temperaturami (powyżej $80^{\circ} \mathrm{C}$ ) oraz dużymi naprężenia- mi ściskającymi (powyżej 55,2 MPa) [15]. W złożach tych do podsadzenia wytworzonej szczeliny stosuje się materiał podsadzkowy o dużej wytrzymałości na wysokie naprężenia ściskające oraz temperaturę [15]. Do badań wykorzystano skałę
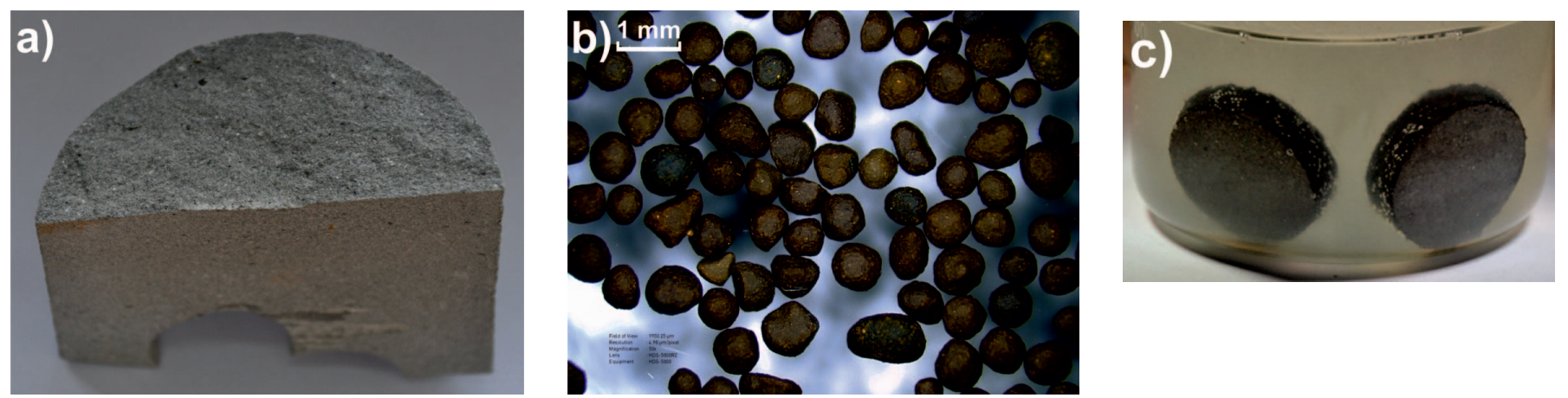

Rys. 6. a) skała złożowa typu zamkniętego: „Piaskowiec tight gas” z polskiego złoża; b) wygląd ziaren podsadzki: „Podsadzka ceramiczna 20/40”; c) cylindryczne rdzenie nasycane w płynie szczelinującym [15] 
piaskowcową typu tight gas, oznaczoną jako „Piaskowiec tight gas" (rysunek 6a), pochodzącą z polskiego złoża. Posiadała ona w swoim składzie między innymi: 37,6\% kwarcu, $19,0 \%$ węglanów oraz $26,7 \%$ minerałów ilastych [15]. Do podsadzenia utworzonej szczeliny została wykorzystana podsadz-

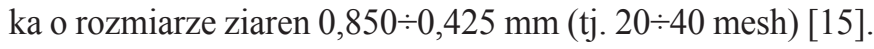
Posiadała ona klasę wytrzymałości na ściskanie $15 \mathrm{~K}$, która odpowiada maksymalnej wartości naprężenia ściskającego 103,4 MPa (tj. 15000 psi), powodującego zniszczenie nie więcej niż 10\% ziaren podsadzki [15, 24-26]. Należy ona do grupy podsadzek ceramicznych o średniej wytrzymałości na naprężenia ściskające (ang. ISP - Intermediate-Strength Proppants). Oznaczono ją jako „Podsadzka ceramiczna 20/40” (rysunek 6b). Do badań użyto również płynu szczelinującego o składzie: woda wodociągowa, środek żelujący (guar), biocyd, środek (stabilizator) zapobiegający pęcznieniu minerałów ilastych i łupkowych oraz przeciwdziałający migracji minerałów ilastych, mikroemulsja (rysunek 6c).

\section{Wykonanie badań laboratoryjnych symulacji wytrzymałości skały złożowej dla efektywnego podsadzenia wytworzonej szczeliny}

Badania wykonano na rdzeniach cylindrycznych o średnicy 2,54 cm (1 cala). W pierwszej kolejności wyznaczono średnią pierwotną chropowatość powierzchni czołowej rdzenia (ściany szczeliny) przedstawionego na rysunku 7. Ustalono ją według procedury badawczej opisanej we wcześniejszej części artykułu. Stanowiła ona średnią arytmetyczną z dwóch wytypowanych obszarów (rysunki 7b i 7c) na powierzchni czołowej badanego rdzenia (rysunek 7a), z jednego profilu biegnącego w poprzek analizowanego obszaru. Testy te wykonano pod mikroskopem stereoskopowym przedstawionym na rysunku 8c [13].

Średnia chropowatość $R_{s r}$ dla całej powierzchni czołowej rdzeni wyniosła 0,00941 $\pm 0,00156 \mathrm{~mm}$.

Następnie wykonano laboratoryjną symulację zjawiska wciskania się ziaren podsadzki w ściany szczeliny dla: podsadzki ceramicznej, jednej koncentracji powierzchniowej podsadzki 4,88 kg/m², naprężenia ściskającego 82,7 MPa, okresu 6 godzin oddziaływania naprężenia ściskającego oraz rdzeni suchych i dodatkowo nasycanych płynem szczelinującym, w temperaturze pokojowej. Badania wykonano na prasie hydraulicznej wyposażonej w szczelinościomierz LVDT, przedstawionej na rysunku $8 \mathrm{a}$, według procedury badawczej zaprezentowanej w tym artykule. Podsadzka była umieszczana pomiędzy dwoma cylindrycznymi rdzeniami skalny- mi (rysunek 8b) w komorze do symulacji zjawiska embedment (rysunek 8a) i poddawana działaniu naprężenia ściskającego przez 6 godzin [15]. Po upływie zadanego czasu zdejmowano naprężenie, rozkręcano komorę i badano powierzchnie czołowe cylindrycznych rdzeni (ściany szczeliny) pod mikroskopem stereoskopowym przedstawionym na rysunku 8c [15]. Całkowitą średnią głębokość wciskania ziaren podsadzki w ściany szczeliny wyznaczano z czterech odcinków pomiarowych dla dwóch obszarów, wytypowanych na powierzchni czołowej górnego oraz dolnego rdzenia. Dodatkowo wykonano badania maksymalnej (pierwotnej) rozwartości szczeliny pomiędzy dwiema stalowymi kształtkami cylindrycznymi o twardości stali 46 HRC (dla wykluczenia zjawiska embedment).

Parametry zestawów dla stalowych kształtek cylindrycznych i cylindrycznych rdzeni skalnych oraz warunki wykonania testów przedstawiono w tablicach 1 i 2 . Na rysunkach 9 i 10 zaprezentowano topograficzny obraz powierzchni rdzeni po testach. Dla każdego analizowanego obszaru wyznaczono cztery odcinki pomiarowe. Wyniki badań całkowitych średnich głębokości wgnieceń ziaren podsadzki w ściany szczeliny przedstawiono na rysunku 11 [15].

Niepewność oszacowanej rozwartości szczeliny wypełnionej materiałem podsadzkowym $W_{f}$, wyznaczona na podstawie
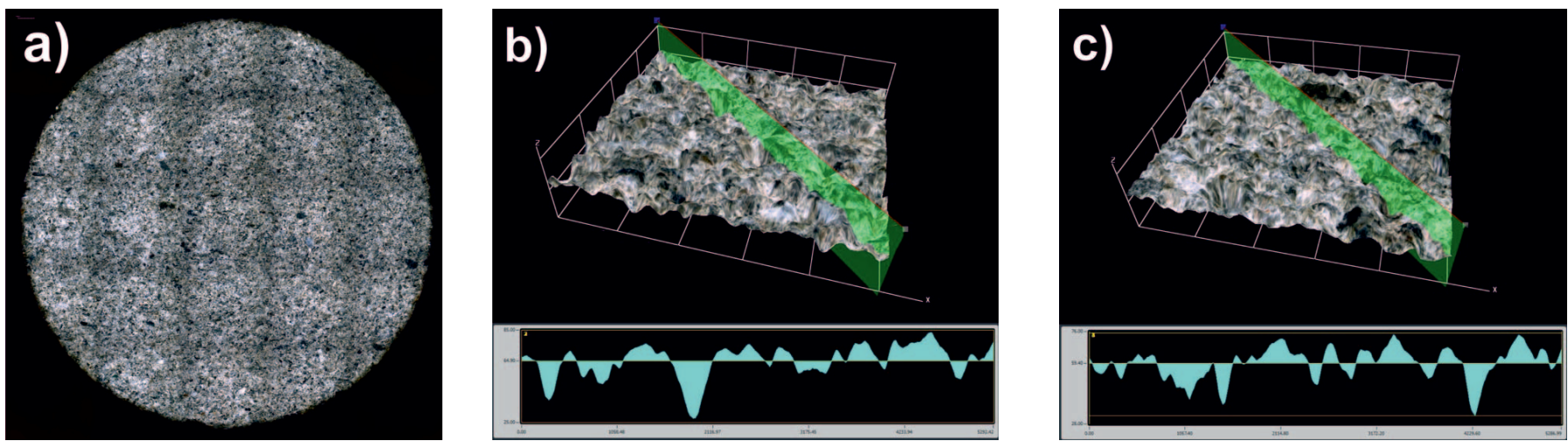

Rys. 7. Określenie pierwotnej chropowatości powierzchni ścian szczeliny dla suchych rdzeni skalnych („Piaskowiec tight gas”) w 3D: a) powierzchnia czołowa rdzenia (pow. 50×); b) obszar nr 1; c) obszar nr 2 [15] 


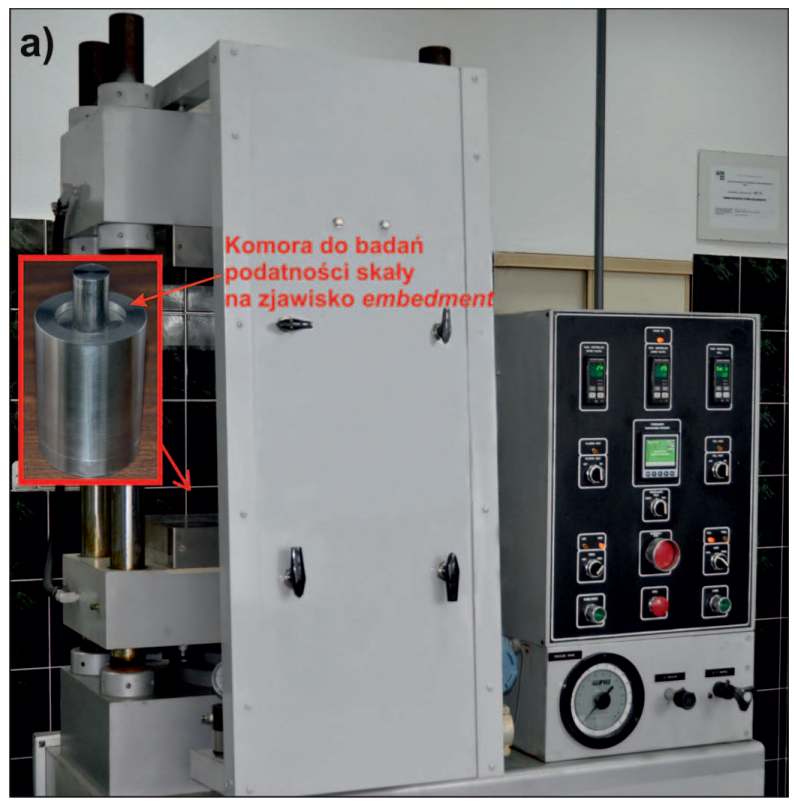

b)
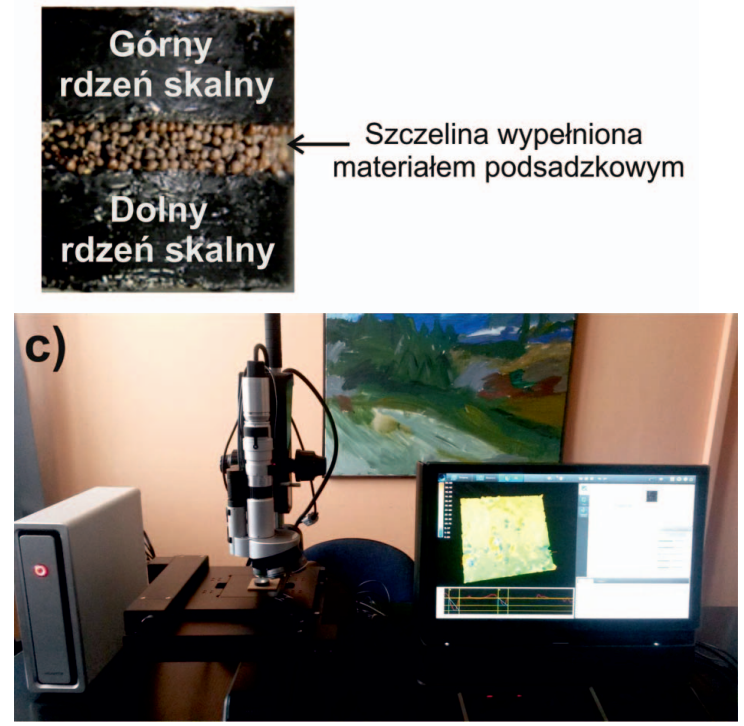

Rys. 8. Wygląd: a) prasy hydraulicznej wraz z komorą o średnicy wewnętrznej 2,54 cm (tj. 1 cala) do badania podatności skały na zjawisko embedment ograniczające efektywne podsadzeni szczeliny podsadzką, w INiG - PIB; b) schematu umieszczenia materiału podsadzkowego w szczelinie; c) mikroskopu stereoskopowego Huvitz [15]

Tablica 1. Parametry zestawów rdzeni użytych w testach

\begin{tabular}{|c|c|c|c|c|c|}
\hline $\begin{array}{l}\mathrm{Nr} \\
\text { testu }\end{array}$ & Nazwa rdzeni & Rdzeń & $\begin{array}{c}\text { Długość } \\
\text { rdzenia } \\
{[\mathrm{mm}]}\end{array}$ & $\begin{array}{l}\text { Średnica } \\
\text { rdzenia } \\
{[\mathrm{mm}]}\end{array}$ & $\begin{array}{c}\text { Pole powierzchni } \\
\text { czołowej rdzenia } \\
{\left[\mathrm{mm}^{2}\right]}\end{array}$ \\
\hline \multirow{2}{*}{1} & \multirow{2}{*}{ Kształtki stalowe o twardości 48 HRC } & górny & 10,00 & 25,40 & 506,45 \\
\hline & & dolny & 10,00 & 25,40 & 506,45 \\
\hline \multirow{2}{*}{2} & \multirow{2}{*}{ Piaskowiec tight gas, suche rdzenie } & górny & 7,18 & 25,16 & 496,93 \\
\hline & & dolny & 7,15 & 25,17 & 497,32 \\
\hline \multirow{2}{*}{3} & \multirow{2}{*}{$\begin{array}{l}\text { Piaskowiec tight gas, rdzenie wcześniej nasycane płynem } \\
\text { szczelinującym przez } 24 \text { godz. (rysunek 6c) }\end{array}$} & górny & 7,21 & 25,25 & 500,49 \\
\hline & & dolny & 7,15 & 25,10 & 494,56 \\
\hline
\end{tabular}

Tablica 2. Warunki wykonania testów nr 1, 2, 3

\begin{tabular}{|l|c|}
\hline Rodzaj materiału podsadzkowego & Podsadzka ceramiczna 20/40 \\
\hline Koncentracja powierzchniowa podsadzki $\left[\mathrm{kg} / \mathrm{m}^{2}\right]$ & 4,88 \\
\hline Temperatura podczas testu $\left[{ }^{\circ} \mathrm{C}\right]$ & pokojowa \\
\hline Zadane naprężenie ściskające $[\mathrm{MPa}]$ & 82,7 \\
\hline Czas działania zadanego naprężenia ściskającego [godz.] & 6 \\
\hline
\end{tabular}

dokładności szczelinościomierza LVDT, wynosiła 0,001 mm. liny, ustalona na podstawie odchylenia standardowego od Niepewność oszacowanej całkowitej średniej głębokości wartości średniej dla poszczególnych profili, nie przekrawciskania ziaren materiału podsadzkowego w ściany szcze- czała 0,0436 mm.
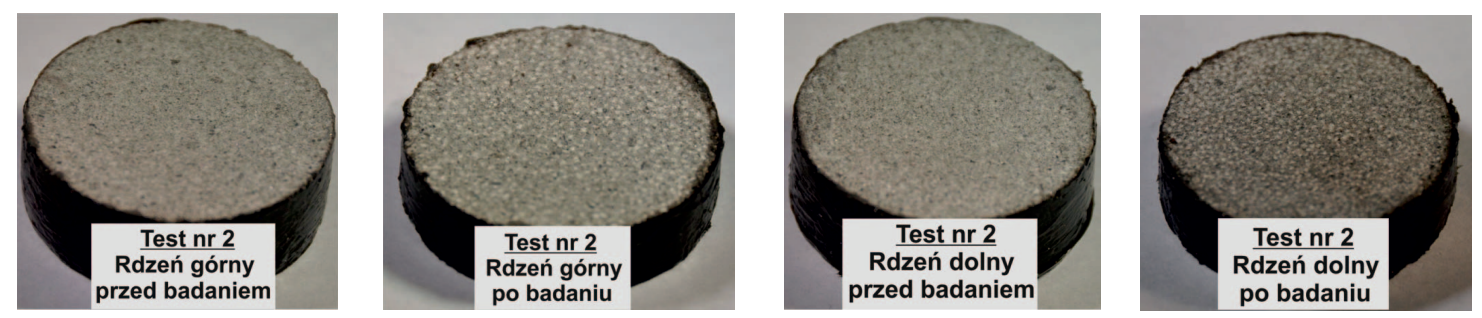

Wygląd powierzchni czołowej rdzenia (ściany szczeliny) 

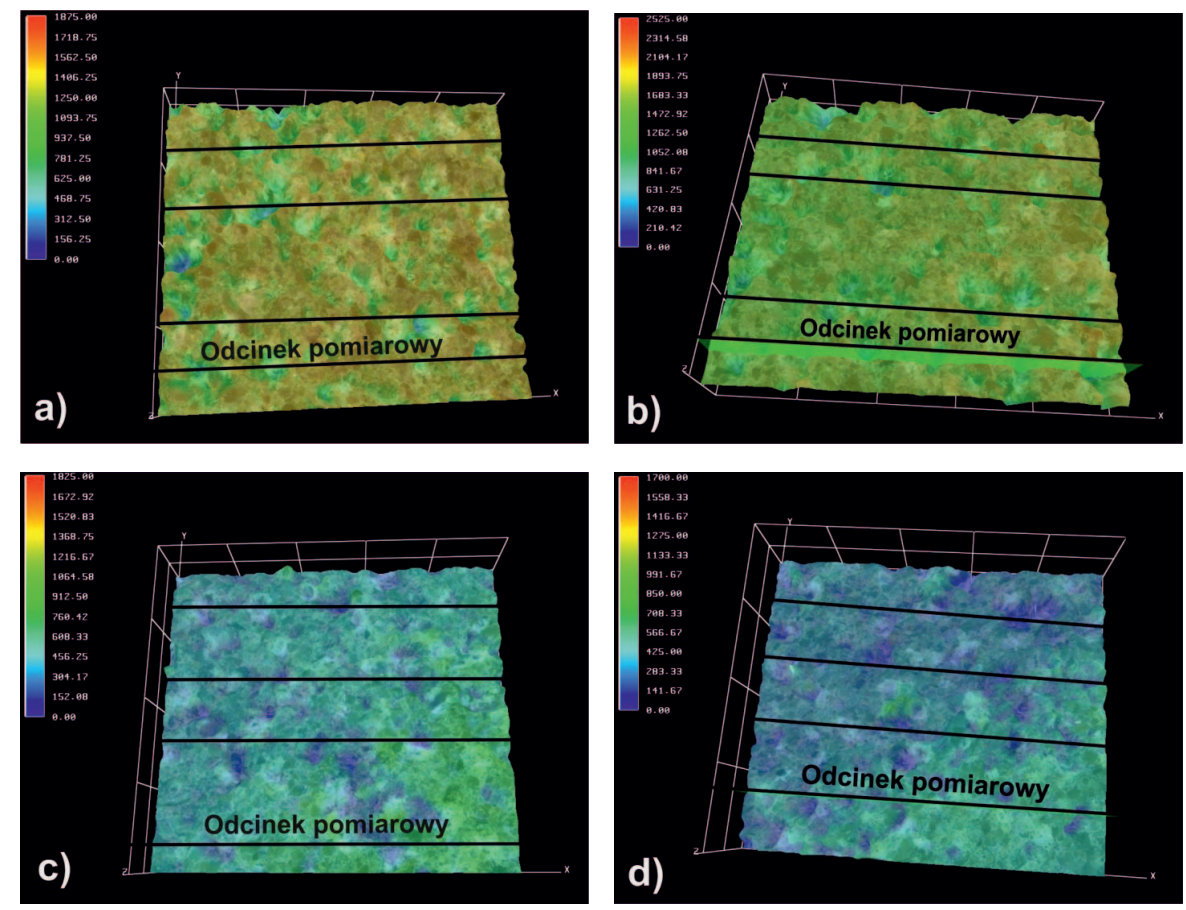

Rys. 9. Określenie średniej głębokości wgnieceń ziaren podsadzki w ściany szczeliny oraz średniego procentowego uszkodzenia powierzchni szczeliny dla testu nr 2, dla górnego rdzenia: a) obszar nr 1, b) obszar nr 2; dla dolnego rdzenia: c) obszar nr 1, d) obszar nr 2 [15]

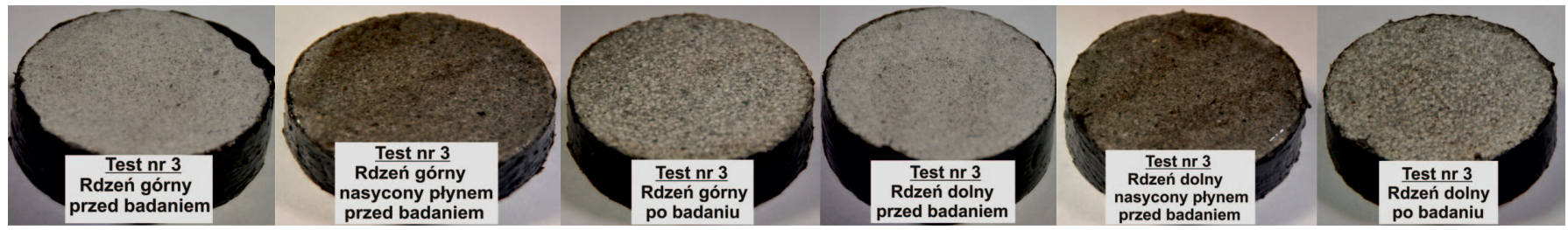

Wygląd powierzchni czołowej rdzenia (ściany szczeliny)
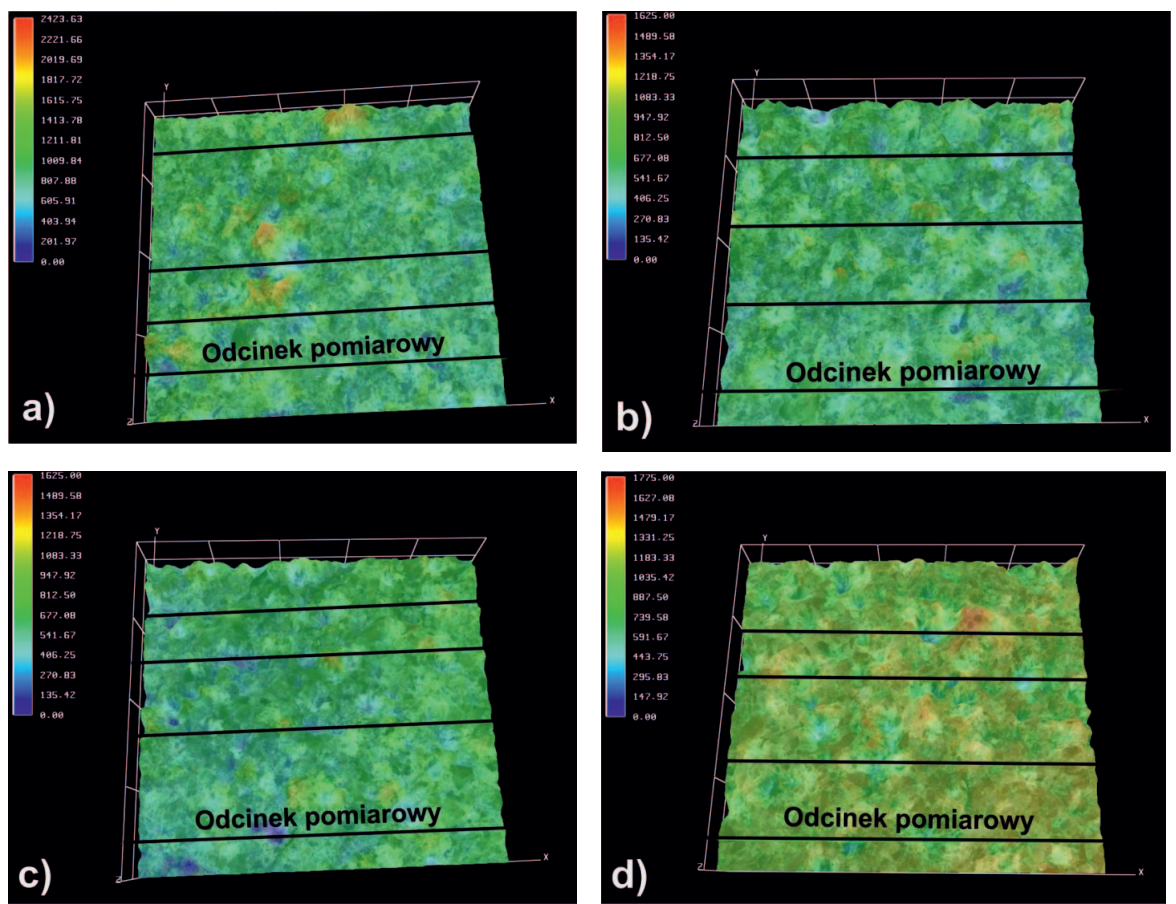

Rys. 10. Określenie średniej głębokości wgnieceń ziaren podsadzki w ściany szczeliny oraz średniego procentowego uszkodzenia powierzchni szczeliny dla testu nr 3, dla górnego rdzenia: a) obszar nr 1, b) obszar nr 2; dla dolnego rdzenia: c) obszar nr 1, d) obszar nr 2 [15] 


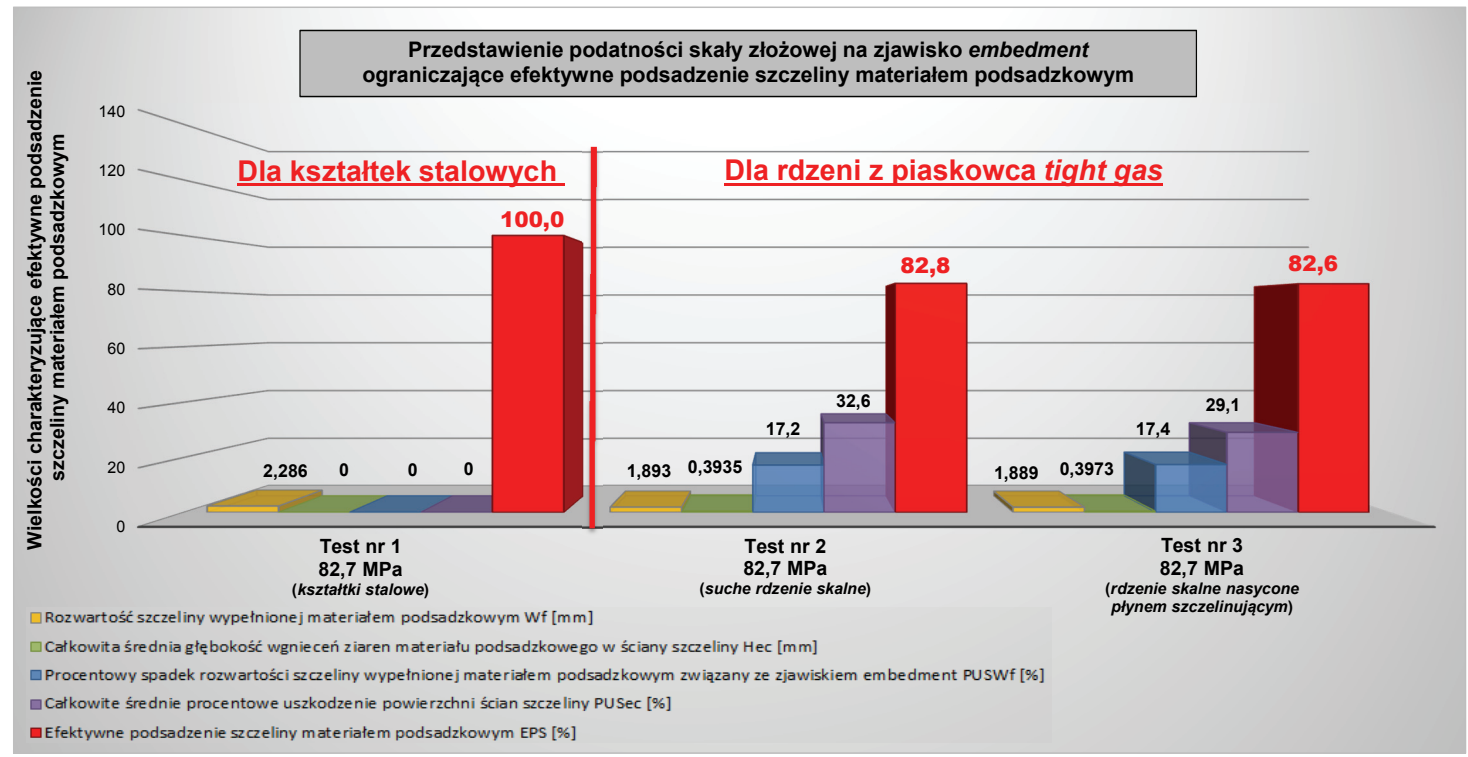

Rys. 11. Podatność skały piaskowcowej tight gas na zjawisko embedment dla podsadzenia szczeliny podsadzką ceramiczną $20 / 40$ o koncentracji powierzchniowej $4,88 \mathrm{~kg} / \mathrm{m}^{2}$, po zabiegu hydraulicznego szczelinowania

\section{Podsumowanie i wnioski}

W artykule przedstawiono wpływ, jaki na efektywne podsadzenie szczeliny generowanej w wyniku zabiegu hydraulicznego szczelinowania ma podatność skały złożowej na zjawisko embedment. W pierwszej kolejności została wyznaczona rozwartość szczeliny wypełnionej podsadzką pomiędzy dwiema cylindrycznymi kształtkami stalowymi. Obrazowało to maksymalną (pierwotną) rozwartość szczeliny, możliwą do uzyskania przy zadanym naprężeniu ściskającym, bez występowania zjawiska embedment, tj. uzyskanie 100,0\% efektywnego podsadzenia wytworzonej szczeliny. Dla zestawu cylindrycznych kształtek stalowych, po 6 godzinach oddziaływania naprężenia ściskającego (rzędu 82,7 MPa), uzyskano szczelinę o rozwartości 2,286 mm. Koncentracja powierzchniowa podsadzki oznaczonej jako „Podsadzka ceramiczna 20/40” wynosiła 4,88 kg/m².

Następnie dla zestawu składającego się z suchych cylindrycznych rdzeni skalnych, oznaczonych jako „Piaskowiec tight gas", po 6 godzinach oddziaływania naprężenia ściskającego (rzędu 82,7 MPa) uzyskano szczelinę o rozwartości 1,893 mm. Koncentracja powierzchniowa „Podsadzki ceramicznej 20/40" wynosiła $4,88 \mathrm{~kg} / \mathrm{m}^{2}$. Całkowita średnia głębokość wgnieceń ziaren podsadzki o rozmiarze $0,850 \div 0,425 \mathrm{~mm}$ w ściany szczeliny osiągnęła wartość $0,3935 \mathrm{~mm}$. W tym przypadku nastąpiło zmniejszenie rozwartości szczeliny o 17,2\% w stosunku do maksymalnej (pierwotnej) rozwartości wyznaczonej bez występowania zjawiska embedment (tj. 2,286 mm). Efektywne podsadzenie szczeliny proppantem dla suchych rdzeni skalnych wyniosło $82,8 \%$.
W przypadku zestawu cylindrycznych rdzeni skalnych dodatkowo nasyconych przez okres 24 godzin płynem szczelinującym (na bazie polimeru naturalnego, tj. guaru) zaobserwowano nieznaczny wzrost całkowitej średniej głębokości wgnieceń ziaren podsadzki w ściany szczeliny, wynoszący 0,3973 $\mathrm{mm}$. W wyniku tego zjawiska następuje zmniejszenie rozwartości szczeliny o 17,4\% w stosunku do maksymalnej (pierwotnej) rozwartości. Tym samym rozwartość szczeliny po 6-godzinnym oddziaływaniu naprężenia ściskającego wyniosła 1,889 $\mathrm{mm}$. Efektywne podsadzenie szczeliny proppantem dla nasyconych płynem szczelinującym rdzeni skalnych osiągnęło wartość $82,6 \%$.

Na podstawie uzyskanych wyników można stwierdzić, iż badana skała złożowa „Piaskowiec tight gas”, zarówno sucha, jak i nasycona płynem szczelinującym, charakteryzuje się dobrymi właściwościami (małą podatnością na zjawisko embedment) umożliwiającymi efektywne podsadzenie wytworzonej szczeliny (utrzymanie jej w stanie rozwarcia) dla naprężenia ściskającego 82,7 MPa, przy zastosowaniu koncentracji powierzchniowej „Podsadzki ceramicznej 20/40” równej $4,88 \mathrm{~kg} / \mathrm{m}^{2}$.

Przedstawiona $\mathrm{w}$ artykule procedura badawcza może stanowić jedną z metod oceny podatności skały złożowej na zjawisko embedment ograniczające efektywne podsadzenie wytworzonej szczeliny oraz jeden z parametrów decydujących o utrzymaniu efektywnej rozwartości szczeliny po zabiegu hydraulicznego szczelinowania. 
Artykuł powstał na podstawie pracy statutowej pt. Badania zjawiska wciskania ziaren materiału podsadzkowego w ściany szczeliny po zabiegu szczelinowania - praca INiG - PIB na zlecenie MNiSW; nr zlecenia: 0020/KS/14; nr archiwalny: DK-4100-20/14.

\section{Literatura}

[1] Akrad O., Miskimins J., Prasad M.: The Effects of Fracturing Fluids Rock Mechanical Properties and Proppant Embedment. SPE 146658, 2011, s. 1-12.

[2] Alramahi B., Sundberg M. I.: Proppant Embedment and Conductivity of Hydraulic Fractures in Shales. ARMA 2012, s. 12-291.

[3] Czupski M., Kasza P., Wilk K.: Ptyny do szczelinowania złóż niekonwencjonalnych. Nafta-Gaz 2013, nr 1, s. 42-50.

[4] Economides M. J., Nolte K. G.: Reservoir Stimulation. Second edition. Houston, 1989

[5] Gidley J. L., Holditch S. A., Nierode D. A., Veatch R. V.: Recent Advances in Hydraulic Fracturing. SPE, 1989.

[6] Guo J., Liu Y.: Modeling of Proppant Embedment: Elastic Deformation and Creep Deformation. SPE 157449, 2012, s. 1-8.

[7] Kasza P.: Zabiegi stymulacji wydobycia w niekonwencjonalnych złożach węglowodorów. Nafta-Gaz 2011, nr 10, s. 697-701.

[8] Kasza P. i in.: Metody stymulacji wydobycia ze złóż typu tight $i$ shale. Dokumentacja INiG, nr zlecenia 26/KS/11, nr archiwalny: DK-4100-26/11, Kraków, październik 2011, s. 1-39.

[9] Kasza P. i in.: Stymulacja wydobycia ze złóż niekonwencjonalnych. Dokumentacja INiG, nr zlecenia 1804/KS/12, nr archiwalny: DK-4100-115/12, Krosno, grudzień 2012, s. 1-59.

[10] Legarth B., Huenges E., Zimmermann G.: Hydraulic fracturing in a sedimentary geothermal reservoir: Results and implications. International Journal of Rock Mechanics \& Mining Sciences 2005 , vol. 42, s. 1028-1041.

[11] Masłowski M.: Badania przewodności warstwy materiału podsadzkowego dla gazu (azotu) po zabiegu hydraulicznego szczelinowania złóż niekonwencjonalnych. Nafta-Gaz 2016, nr 3, s. 177-185.

[12] Masłowski M.: Badania zjawiska wciskania ziaren materiału podsadzkowego w ściany szczeliny po zabiegu hydraulicznego szczelinowania złóż niekonwencjonalnych. Nafta-Gaz 2015, nr 7, s. 461-471.

[13] Masłowski M.: Materiały podsadzkowe do zabiegów hydraulicznego szczelinowania złóż niekonwencjonalnych. Nafta-Gaz 2014, nr 2, s. 75-86.

[14] Masłowski M., Czupski M.: Podstawowe właściwości materiałów podsadzkowych stosowanych do zabiegów hydraulicznego szczelinowania złóż węglowodorów. Przegląd Górniczy 2014, nr 12, s. $44-50$.

[15] Masłowski M. i in.: Badania zjawiska wciskania ziaren materiatu podsadzkowego $w$ ściany szczeliny po zabiegu szczelinowania. Praca statutowa INiG - PIB, nr zlecenia 20//KS/14, nr archiwalny: DK-4100-20/147, Krosno, październik 2014, s. 1-78.

[16] Masłowski M. i in.: Badanie wpływu płynów szczelinujących na uszkodzenie hydroprzewodności szczeliny wypetnionej materiałem podsadzkowym $w$ złożach węglowodorów. Praca statutowa INiG - PIB, nr zlecenia 33/KS/15, nr archiwalny: DK-4100-33/15, Krosno, wrzesień 2015, s. 1-74.

[17] Masłowski M. i in.: Opracowanie metodyki badania materiałów podsadzkowych do zabiegów szczelinowania złóż niekonwencjonalnych. Praca statutowa INiG, nr zlecenia $80 / \mathrm{KS} / 13$, nr archiwalny: DK-4100-80/13, Krosno, październik 2013, s. 1-53.

[18] Morales H.: Sustaining Fracture Area and Conductivity of Gas Shale Reservoirs for Enhancing Long-Term Production and Recovery.

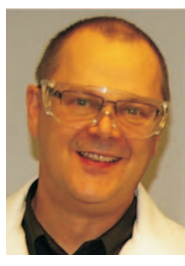

Dr inż. Piotr KASZA

Adiunkt; kierownik Zakładu Stymulacji Wydobycia Węglowodorów.

Instytut Nafty i Gazu - Państwowy Instytut Badawczy ul. Lubicz 25 A

31-503 Kraków

E-mail: piotr.kasza@inig.pl
RPSEA Unconventional Gas Conference 2012: Geology, the Environment, Hydraulic Fracturing, Canonsburg, 17-18.04.2012.

[19] Reinicke A., Legarth B., Zimmermann G., Huenges E., Dresenn G. Hydraulic Fracturing and Formation Damage in a Sedimentary Geothermal Reservoir. ENGINE - Enhanced Geothermal Innovative Network for Europe Workshop 3, "Stimulation of reservoir and microseismicity" Kartause Ittingen, Zürich, 29.06-1.07.2006.

[20] Reinicke A., Rybacki E., Stanchits S., Huenges E., Dresen G.: Hydraulic fracturing stimulation techniques and formation damage mechanisms - Implications from laboratory testing of tight sandstone - proppant systems. Chemie dee Erde 70, 2010, s. 107-117.

[21] Sato K., Ichikawa M.: Post-Frac analysis indicating multiple fractures created in a volcanic formation. SPE 39513, 1998 Proceedings SPE India Oil and Gas Conference and Exhibition, New Delhi 1998, s. 1-10.

[22] Terracina J. M., Turner J. M., Collins D. H., Spillars S. E.: Proppant Selection and Its Effect on the Results of Fracturing Treatments Performed in Shale Formations. SPE 135502, 2010, s. 1-17.

[23] Volk L. J., Raible C. J., Carrol H. B., Spears J. S.: Embedment of high strength proppant into low-permeability reservoir rock. SPE/ DOE 9867, 1981, s. 1-15.

\section{Akty prawne i normatywne}

[24] International Standard ISO 13503-2:2006(E): Petroleum and natural gas industries - Completion fluids and materials - Part 2: Measurement of properties of proppants used in hydraulic fracturing and gravel-packing operations, Annex A - Formazin solution preparation. First edition, 1.11.2006, s. 1-28.

[25] International Standard ISO 13503-2:2006/Amd.1:2009(E): Petroleum and natural gas industries - Completion fluids and materials - Part 2: Measurement of properties of proppants used in hydraulic fracturing and gravel-packing operations, AMENDMENT 1: Addition of Annex B: Proppant specification. 1.11.2009, s. 1-5.

[26] Polska norma PN-EN ISO 13503-2: Przemyst naftowy i gazowniczy - Płyny i materialy do dowiercania złóż - Część 2: Pomiary właściwości materiatów podsadzkowych używanych podczas zabiegów hydraulicznego szczelinowania oraz wykonywania obsypki żwirowej (ISO 13503-2:2006). Polski Komitet Normalizacyjny. Warszawa, styczeń 2010.

[27 Polska norma PN-EN ISO 13503-5: Przemyst naftowy $i$ gazowniczy - Materialy i płyny do dowiercania złóż - Część 5: Procedury pomiaru dlugotrwałej przewodności materiałów podsadzkowych (ISO 13503-5:2006). Polski Komitet Normalizacyjny, Warszawa, wrzesień 2009, s. 1-29.

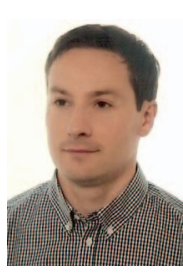

Mgr inż. Mateusz MASŁOWSKI

Asystent w Zakładzie Stymulacji Wydobycia

Węglowodorów.

Instytut Nafty i Gazu - Państwowy Instytut Badawczy ul. Lubicz 25 A

31-503 Kraków

E-mail: mateusz.maslowski@inig.pl

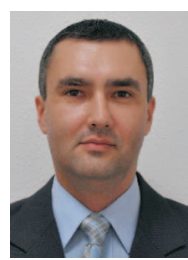

Dr inż. Marek CZUPSKI

Adiunkt w Zakładzie Stymulacji Wydobycia

Węglowodorów.

Instytut Nafty i Gazu - Państwowy Instytut Badawczy ul. Lubicz 25 A

31-503 Kraków

E-mail: marek.czupski@inig.pl 